\title{
Directional layouts in central lowland Maya settlement
}

Bevan, Andrew; Jobbová, Eva; Helmke, Christophe; Awe, Jaime

Published in:

Journal of Archaeological Science

DOI:

10.1016/j.jas.2013.01.011

Publication date:

2013

Document version

Publisher's PDF, also known as Version of record

Citation for published version (APA):

Bevan, A., Jobbová, E., Helmke, C., \& Awe, J. (2013). Directional layouts in central lowland Maya settlement. Journal of Archaeological Science, 40, 2373-2383. https://doi.org/10.1016/j.jas.2013.01.011 


\title{
Directional layouts in central lowland Maya settlement
}

\author{
A. Bevan ${ }^{\text {a,* }}$, E. Jobbováa ${ }^{a}$, C. Helmke ${ }^{\text {b }}$, J.J. Awe ${ }^{c}$ \\ a Institute of Archaeology, University College London, 31-34 Gordon Square, London WC1H OPY, United Kingdom \\ ${ }^{\mathrm{b}}$ Institute of Cross-Cultural and Regional Studies, University of Copenhagen, Artillerivej 86, 2300 Copenhagen S, Denmark \\ ${ }^{\mathrm{c}}$ Institute of Archaeology, Archaeology Museum and Research Centre, Culvert Road, Belmopan, Belize
}

\section{A R T I C L E I N F O}

\section{Article history:}

Received 1 August 2012

Received in revised form

8 January 2013

Accepted 10 January 2013

\section{Keywords:}

Anisotropy

Point patterns

Latin America

Urbanism

\begin{abstract}
A B S T R A C T
This paper suggests the existence of non-random, directional patterns in the location of housemounds across the Late Classic Maya settlement landscape at Baking Pot, Belize, and then explores the wider implications of this patterning in the central Maya lowlands. It introduces an anisotropic method based on nearest neighbour bearings and successive grid offsets - in order to explore possible rectilinear organisation in settlement layouts despite the presence of uneven and irregular patterns of archaeological dating and recovery. The results suggest a grid-like distribution of houseplots and, by implication, also a set of routes running throughout the housemound landscape and local Maya neighbourhoods during the site's Late and Terminal Classic history. Furthermore, different possible alignments in different parts of the site are tentatively regarded as an indication of shifting orientations to localised grids, following the shift in alignment of monumental architecture, as the settlement landscape expanded over time. Finally, we discuss the implications of these findings with respect to the broader interpretation of Maya settlement patterns.
\end{abstract}

(c) 2013 Elsevier Ltd. All rights reserved.

\section{Introduction}

Maya archaeology exhibits a curious combination of obsession and disinterest when it comes to the study of directional patterns in the built landscape. On the one hand, there is an established, if often hotly debated, literature on the alignments of Maya monumental buildings and what they might mean in terms of changing political fortunes, religious priorities or astronomical knowledge (Aveni, 2001; Aveni et al., 2003; Šprajc, 2008). On the other hand, the wider landscape beyond the monumental epicentres of Maya sites is traditionally seen as a dispersed free-for-all, in which both field systems and non-elite habitations are scattered in a regionally variable and, in comparison to monumental epicentres, far less formal way (for a clear summary, see Ashmore, 1981). Despite this, many commentators have nonetheless considered the relative spacing of Maya settlement as an important piece of empirical evidence for the nature of small-scale agricultural strategies and higher-order political organisation (Becker, 2001; Garber et al., 1993; Helmke and Awe, 2008a, 2013; Dunning, 2004; Hutson et al., 2004, 2007; Lohse, 2004; Mathews, 1991; Yaeger and Robin, 2004). Furthermore, an increasing number of studies of rural settlement and spatial organisation have also begun to question

\footnotetext{
* Corresponding author. Tel.: +44 2076791528

E-mail address: a.bevan@ucl.ac.uk (A. Bevan).
}

the traditional dichotomy that distinguishes Maya urban from rural spaces (Iannone and Connell, 2003; Manaham and Canuto, 2009; Marken, 2011).

In this paper, we build upon this wider sense of the regional variability and more mixed urban and rural characteristics exhibited by Maya settlements, and further question the assumption that it is only the monumental core of a site that shows any degree of formal spatial alignment. In so doing, we also consider the spatial analytical methods currently available for exploring and confirming patterns of non-random directionality in human settlement. In particular, emphasis is placed on a nearest neighbour bearing and grid offset technique that is fairly robust to the poorly-preserved, inconsistently-dated and otherwise patchy settlement data that we typically recover from surface survey (and for which there are substantial published records from the Maya area). As a case study, we consider the unusually well-explored major site of Baking Pot in west-central Belize. The first section introduces this dataset and offers some informal speculation about the human use of space across the Baking Pot landscape, particularly with regard to the Late and Terminal Classic period where our evidence is strongest (c. AD 550-950). The following section offers a review of anisotropic methods in spatial analysis, as applied both within and beyond archaeology, as well as introducing a modified version of existing techniques that we propose is helpful with regard to archaeological data and archaeological questions. We then consider the results by applying this method to the Baking Pot data and suggest that they 
support a view of the wider Baking Pot landscape as consisting of fairly well-defined houseplot neighbourhoods and routes, above and beyond those visible as monumental causeways and plazuela groups. The final section then addresses the broader implications of these findings for Maya settlement and community archaeology.

\section{Case study and problem orientation}

Baking Pot is located in the present-day Cayo District of westcentral Belize, on the southern bank of Belize River (Fig. 1). It was probably first occupied in the Middle Preclassic (ca. 600-300 BC), but did not reach its demographic and political peak until the Late Classic period (ca. 550-830 AD) at which point it served as the major centre of a polity with an overall population previously estimated at 1040-1360 people per sq km (Conlon and Awe, 1995: 66-74). Early investigations of the area focused on excavating the monumental epicentre, comprising two large architectural complexes linked by a causeway (Ricketson, 1929; Willey et al., 1965: 305-9; Bullard and Bullard, 1965; Helmke and Awe, 2008b). From the 1960s onwards, however, the broader settlement landscape of housemounds and plazuela groups was also explored by surface survey and limited test excavation, covering both the area around Baking Pot itself and neighbouring zones, such as Barton Ramie and Spanish Lookout. Although the initial settlement surveys were conducted by William Bullard as part of Gordon Willey's pioneering settlement pattern survey of the Belize Valley (Willey et al., 1965), the bulk of the settlement surveys and excavations conducted at Baking Pot have been undertaken by the Belize Valley Archaeological Reconnaissance Project under the direction of Jaime Awe.
This landscape-scale research duly uncovered hundreds of housemounds, several formal and informal plazuela groups, and a few non-domestic structures extending out from the monumental epicentre in densities much greater than in the regions of the Belize and Mopan valleys further west, (i.e. greater than those around Cahal Pech or Xunantunich; see Chase and Garber, 2004: 10). More importantly, the resulting survey coverage is also unique in the Maya world, to our knowledge, in offering a window on the entire settlement continuum of a small Maya polity (with the rough extent of the latter suggested by perceived gaps in the settlement continuum as well as both archaeological and epigraphic modelling; Helmke and Awe, 2008a, 2013; Driver and Garber, 2004: 289292).

Since the introduction of settlement pattern surveys in the Maya area, settlement archaeology, focusing on households and midlevel structures has become a major strand of archaeological research in the Maya lowlands, especially over the last few decades (e.g. Iannone and Connell, 2003; Douglass, 2002; Yaeger, 2000). It has addressed both large and small-scale structures, but its focus has largely been on understanding artefact assemblages or offering general impressions of relative mound density or spacing. For instance, along the Belize river, there is a fairly consistent intensity of settlement, with major (often demonstrably royal) centres spaced roughly every $10 \mathrm{~km}$ and minor centres then often located at the likely boundaries between them (Driver and Garber, 2004: 289-292; Helmke and Awe, 2008a: 76-78, 2013: 70-72), suggesting the division of the lowlands into polities with fairly discrete territories. These different polity areas are likely to reflect competition for human and agricultural resources, agricultural

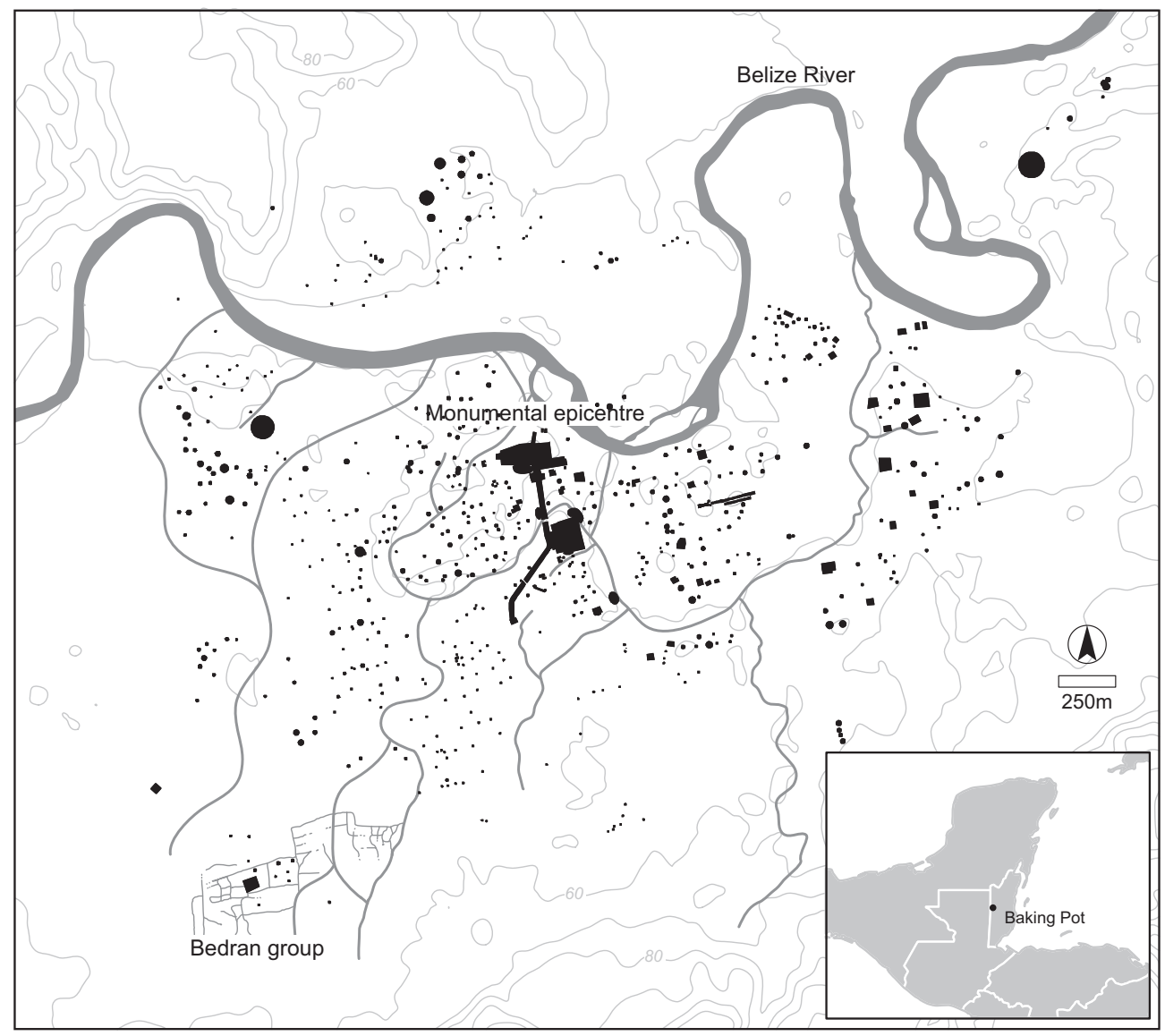

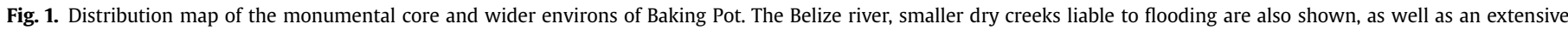

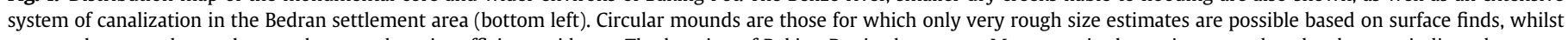
rectangular mounds are shown wherever there is sufficient evidence. The location of Baking Pot in the greater Maya area is shown inset; modern borders are indicated. 
catchments as well as the geography of interaction afforded by the Belize valley and river (Chase, 2004: 347).

Despite an existing emphasis on settlement survey and nonelite community archaeology, there has been comparatively little formal analysis of the directional layout of wider settlement landscapes, in contrast to the emphasis on the alignments within plazuelas and major monuments or for formally defined and archaeologically obvious routes such as monumental causeways (e.g. Becker, 1971, 1999; Chase and Chase, 1994, 2001; Normark,
2006; Stuart, 2006). To our knowledge, there has been very little published speculation about directional patterns in lowland Maya settlement mounds, with an interesting local exception being Willey et al.'s comments nearly fifty years ago (1965: 296, Fig. 173) about possible rows of housemounds at Spanish Lookout, $4 \mathrm{~km}$ northeast of Baking Pot.

With this brief comment in mind, we can now take a closer look at the surveyed area around Baking Pot (Fig. 2a). Most of the area has been used for pasture and maize agriculture for several decades
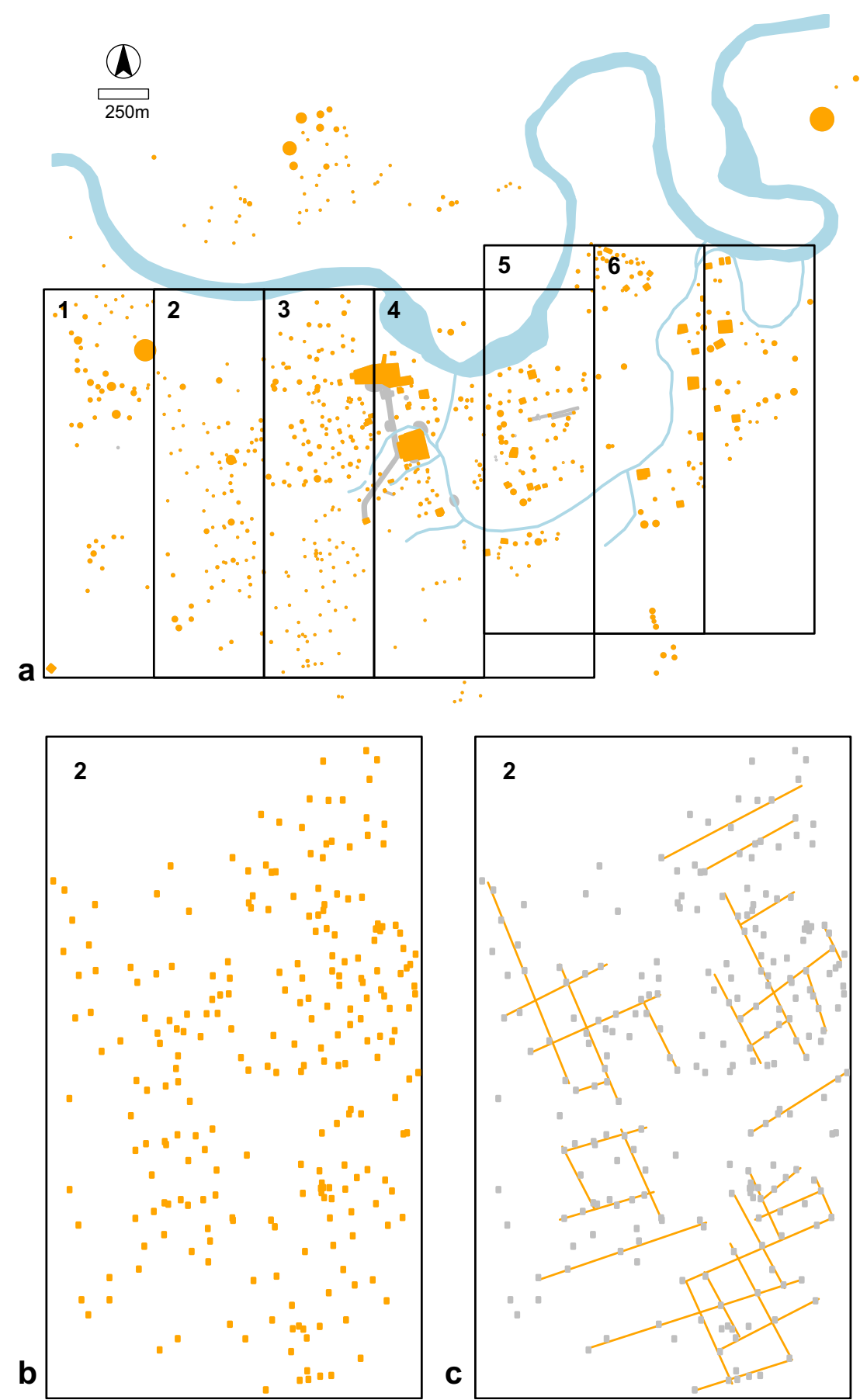

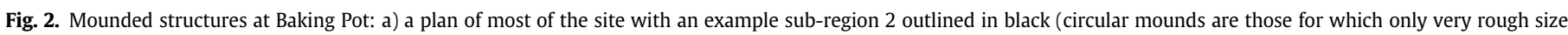

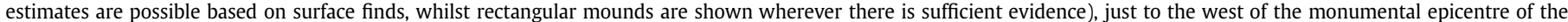

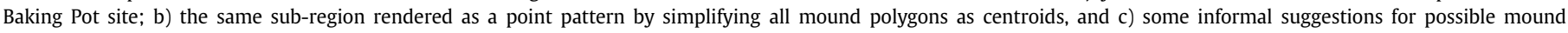
alignments in this sub-region. 
and recent ploughing has been responsible for further truncating and dispersing many of the surviving mounds. However, this modern activity has also led to very good surface visibility, rarely impeded by the kinds of sub-tropical vegetation that cover so many other sites in the region (e.g. Healy et al., 2007: 22-23, Fig. 5). Surface artefacts associated with the mounds include ceramics, knapped and ground stone and shell amongst other artefact categories. While earlier surveys concentrated on the monumental epicentre of Baking Pot and the settlement mounds immediately to the east (Bullard and Bullard, 1965: 7-10; Willey et al., 1965: 301305), more recent work by the Belize Valley Archaeological Reconnaissance project has both explored further to the west and linked it up with earlier surveys of Spanish Lookout and Barton Ramie to the east and Bacab Na to the west (e.g. Conlon and Ehret, 2000; Hoggarth et al., 2008). Housemounds from early surveys were originally plotted on fine scale maps, whereas those in the 1990s were fixed by theodolite surveys. Recent survey since 2007 has been conducted by fieldwalkers spaced 5-10 m apart who have fixed the locations of observed mounds by handheld GPS (further corrected for daily drift in these measurement by reference to a fixed point at known times each day). These different surveys have now been integrated as vector polygons and lines that record a mound's location, size, and where possible its internal structure and dating of its occupation/use. The resulting dataset has a working horizontal positional accuracy of at least $\pm 10 \mathrm{~m}$ (usually $\pm 5 \mathrm{~m}$ ) and offers a large and comparatively uniform coverage over $9 \mathrm{sq} \mathrm{km}$ that is almost unrivalled in the Maya lowlands, and probably unique in its coverage of an entire small Maya polity.

Several basic, informal points about this distribution of settlement are worth making from the outset. First, the overall Baking Pot region exhibits a fairly dense distribution of a few larger and many smaller mounds, found in clusters across the north and south sides of the Belize River. This constitutes an average density of some 0.8-1.0 mound per hectare depending on the degree to which large tracts of intervening open space are retained or excluded in the calculation. In fact, the patchiness of this settlement pattern renders any straightforward mean estimate such as this misleading, and raises further formal analytical challenges that we come back to below. How do we explain the gaps in this distribution? Modern vegetation cover may sometimes have led to one or two mounds being missed by the surveyors, but the unusually good visibility noted above across much of the area means that, in general, we can attribute such gaps to one of three other factors: (a) old floodplains adjacent to the river that are liable to flooding and were never settled in the past, (b) subsequent river movement that has destroyed areas previously covered in housemounds, (c) microcatchments prompted by the location of small creeks and very subtle accompanying topographic differences and/or (d) deliberate open space in the original settlement layout, unrelated to riverine dynamics, which were used for farming rather than habitation. On balance, it is likely that all of these factors are involved to some degree. Second, we will later consider variation across a series of sub-regions of the Baking Pot area (Fig. 2a), but for now, if we look closely at the distribution of housemounds in one of these (Fig. 2b), then the eye of faith might be tempted to identify (a) a regular spacing between some of these mounds, despite areas where there are also clusters of several mounds and (b) some vague alignments of mounds stretching out in the same direction.

This paper takes these informal suspicions as a starting point and explores ways in which we can test them in a formal manner, with a particular focus on the question of directionality. It starts by considering what statistical methods are most appropriate to study what is still, despite the high levels of archaeological visibility and care taken in recovery, a noisy survey dataset. Thereafter we focus on one method for further exploring patterns of possible directionality in housemounds, and leads us to assess with greater confidence that these directional patterns do indeed exist, but vary in interesting ways across different portions of the overall Baking Pot landscape. A final section therefore goes on to address what the wider implications of these observations might be.

\section{Methods}

In Maya archaeology, a range of spatially-sensitive techniques have been used to understand settlement patterning, particularly with regard to the cessation of monumental construction at the end of the Terminal Classic (Bove, 1981; Whitley and Clark, 1985; Kvamme, 1990; Williams, 1993; Neiman, 1997; Premo, 2004), but also with respect to Maya settlement size, spacing and shape (Ashmore, 1981; Houston, 1993; Brown and Witschey, 2003). Here, however, we focus on the assessment of a pure point pattern of an entire site, not a fraction thereof, where we make the simplifying assumption that individual mounds can be represented by a single point at their centres, ignoring their physical properties, shape and extent, number of surface artefacts, etc. The latter evidence is clearly of interest in other situations and there are plenty of spatial methods relevant to analysing them, but there are benefits to keeping a focus on pure configuration and directionality in what we discuss below.

Point pattern techniques have a fairly long history in adjacent disciplines such as geography and ecology, and some of the simpler approaches, such as Clark and Evans tests and quadrat counts, have been used in archaeology since the 1960s and 1970s (see Hodder and Orton, 1976). Since then, the development of spatial statistics as a sub-discipline of its own has lead to a wider, more sophisticated range of methods for exploring point patterns and fitting formal models of the possible processes that might have generated these patterns (e.g. Gelfand et al., 2010; Illian et al., 2008). We will not consider the vast bulk of these procedures here (for other recent archaeological examples, see Orton, 2004; Bevan and Conolly, 2006; Crema et al., 2010; Bevan et al., in press), but instead retain an emphasis on the well-known concept of nearest neighbour distances in what follows, albeit with several additional modifications.

Fig. 3a shows the main part of Baking Pot, with the mound centroids expressing a point pattern. The coloured values in the background are a kernel density surface that offers a useful way to summarise the way the density of these mounds varies across the whole study area (for further details of the method, see de Smith et al., 2009: 126-34). This surface will also be of use further on when we wish to control for the overall trend of groups of mounds with gaps between them. If we now measure the distance from each mound centroid to its nearest neighbour, we obtain an average of $47.6 \mathrm{~m}$ and the median of $43.2 \mathrm{~m}$. However, it is more useful to look at the whole frequency distribution of nearest neighbour distances (the bars in Fig. 3b). This shows that most mounds have a neighbour 20-60 m away, as the summary statistics already suggested. An important point to establish is whether this distribution of nearest neighbour distances is one that we could expect by chance or not (i.e. is it random?). Traditionally, a quadrat count or Clark and Evans test would have been used for this purpose, but a more robust method would be one in which we repeatedly simulate (in this case 999 times) similar numbers of random points in the same study area and compare these distributions to the observed one (i.e. Monte Carlo simulation, see Robert and Casella, 2004; Wilson and Melnick, 1990 for a similar approach with archaeological sites).

The dotted lines in Fig. 3b show the 95\% envelope of expected values for each histogram bin based on 999 separate simulations of random points. To put this in simpler terms, the second bar on the 

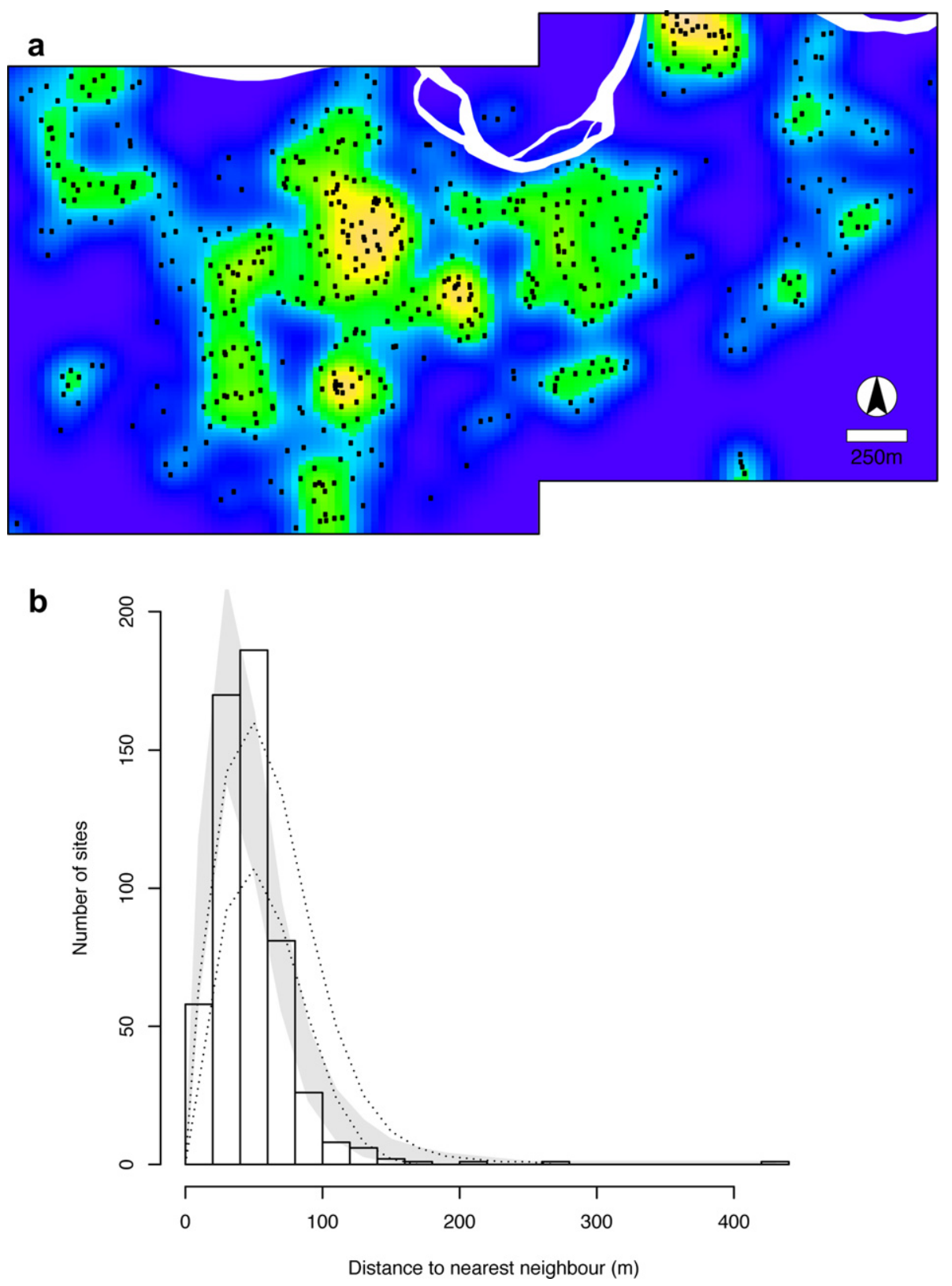

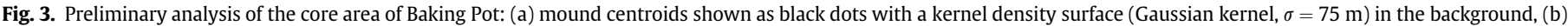

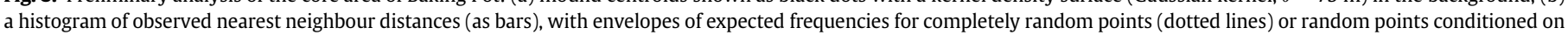
the kernel density surface (grey polygon). The envelopes cover 95\% of the results from 999 iterations.

chart reports that 170 mounds were observed to have nearest neighbour between 20 and $40 \mathrm{~m}$ away. If we simulate a similar number of random points in the study area and look at the nearest neighbour distribution from this random set, we may find it has more or less than 170 mounds in the 20-40 m histogram bin. If we repeat the process for 999 sets of random points, we can say fairly firmly whether the observed count of 170 in the $20-40 \mathrm{~m}$ bin can be expected or not. The dotted envelope is then a way of summarising the histograms for 999 random sets and providing a useful guide to likely statistical significance, by reporting the near-largest and near-smallest (97.5th and 2.5th percentiles approximately) counts recorded for that bin across all 999 random sets. Overall it is clear that we have more mounds than we might expect by chance with neighbours 20-60 m away and fewer than we might expect, over $80 \mathrm{~m}$ away. In other words, our mounds are closer together than we might expect by complete chance.
Unfortunately, this merely confirms something we could observe intuitively in Figs. 1 and 3a: mounds are found in clusters, with gaps between them, and a possible buffer zone towards the edge of the entire polity, rather than spread consistently over the entire study area. We can explore whether there might be more interesting patterns lurking behind this by changing the way we construct our randomisation test. Instead of producing completely random sets within the study area, we can produce sets that are largely random except for the condition that their approximate densities across the study area match the general trend summarised by the kernel density surface. In other words, where there are observed clusters, we will place more random points and where there are observed gaps we will place far fewer. The grey shaded envelope in Fig. 3b summarises the results if we do this for 999 sets again. This time, it is clear that there are fewer mounds than we might expect with neighbours $0-40 \mathrm{~m}$ away, more than we might 
expect from 40 to $60 \mathrm{~m}$ and fewer again thereafter. In other words, once we take account of the overall clumping/clustering of mounds and gaps between them, there is a further pattern of short distance regularity in the spacing of mounds.

There are more sophisticated ways that we could perform this kind of analysis (e.g. using $\mathrm{K}$ functions and fitting point process models: Gelfand et al., 2010; Illian et al., 2008) and more formal ways in which we could describe this combination of a general unevenness in mound density with localised separations among neighbouring mounds (e.g. as first- and second-order properties, or several scales of the latter; Bevan et al., in press). However, Fig. 3a$\mathrm{b}$ are sufficient to make the point that our distribution of mounds (a) has an uneven density across the study area, and beyond this, (b) also exhibits regular spacing at short distances, with many mounds 40-60 m apart. It is also worth remembering again that this settlement data is chronologically noisy. As such, we should not press the above argument about spacings to extend diachronically to all periods, although there is a high probability that the pattern is viable for the Late-Terminal Classic since the site's demography peaked and the vast majority of structures were inhabited and/or utilised during this time period. Further, if the chronological noise was completely overwhelming, we would not expect to have a significant pattern of this kind, so the $40-60 \mathrm{~m}$ spacing should still lead us to think into terms of a Late-Terminal Classic preference for not dwelling too close to a neighbouring family. In practical terms, we could suggest that small plots of land were reserved for the use of individual families immediately around their dwellings and that this kind of landholding inhibited neighbouring dwellings being built too close (e.g. Graham, 1999; Becker, 2001; Trigger, 2003: 300-307). These plots would cover about $500-600 \mathrm{~m}^{2}$, so might be useful for small gardens and various kinds of craft activity, but would certainly need to be supplemented by other agricultural holdings, in the nearby gaps of floodplain within Baking Pot and/or much further afield (see Conlon and Awe, 1995; Conlon, 1997).

To some extent, the analysis above simply revisits a longestablished agenda in the spatial analysis of archaeological sites, the degree to which site spacing can inform us about competition over resources, subsistence catchments and/or territoriality. However, our main interest in this paper, both methodologically and substantively, is to consider possible patterns of directionality or what might more formally be called anisotropy. There is a wide range of ways to explore anisotropy, both in terms of a pure pattern of points and if we wish to look for directional effects in some attribute value associated with those points (Bartlett, 1964; Rayner and Golledge, 1972; Haynes and Enders, 1975; Fry, 1979; Oden and Sokal, 1986; Falsetti and Sokal, 1993; Mugglestone and Renshaw, 1996; Dale and Mah, 1998: 205; Haase, 2001; Rosenberg, 2000; Illian et al., 2008: 253-4; Nicolis et al., 2010) and some limited exploration of these in archaeology (Bevan and Conolly, 2009: 258-259; Markofsky and Bevan, 2011; Benito-Calvo and de la Torre, 2011). Our main objective with the analysis below departs from the methodological emphasis of these few existing archaeological examples: it deliberately retains a comparatively simple metric based on neighbour distances and ascertains whether or not neighbouring mounds at Baking Pot do or do not exhibit nonrandom alignments with one another.

More precisely, we start from our informal hypothesis that there might be grid-like alignments in the Baking Pot settlement data and develop a method which tests for this, based on the bearing from each mound to one or more of its closest neighbours. Fig. 4 offers a simple example in which there are three points (A, B and $C)$ : point A's nearest neighbour is $B$ and the ordinary compass bearing for this is $35^{\circ}$. A's second closest neighbour is $C$ on a bearing of $322.5^{\circ}$. If we were to assume a grid oriented exactly north-south, then the deviation of these two bearings from that grid would be

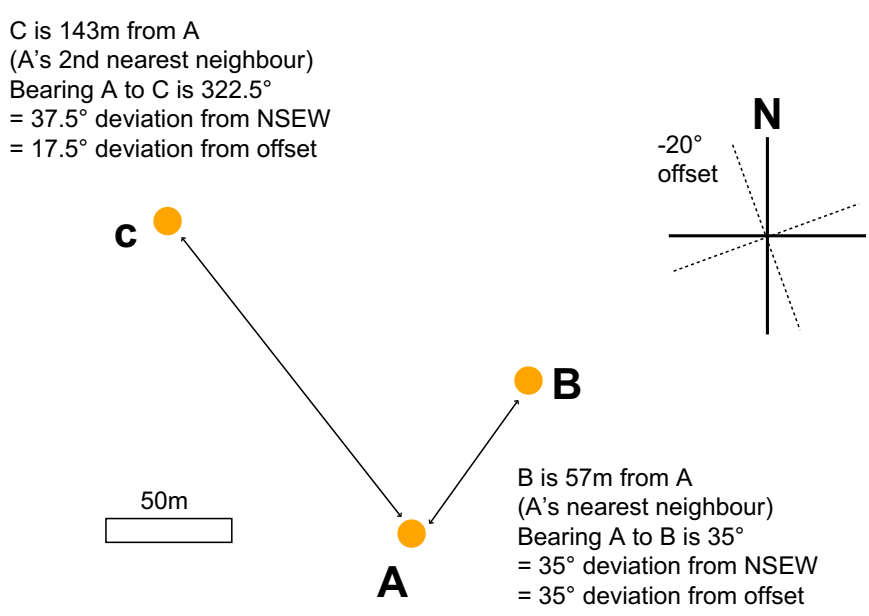

Fig. 4. Schematic example of considering the deviation of nearest neighbour bearings from a known grid. The traditional point of reference for bearings is grid north or magnetic north, but we can also consider deviation from any offset grid, for which the maximum offset is $45^{\circ}$.

$35^{\circ}$ and $37.5^{\circ}$ respectively (no deviation being able to be more than $45^{\circ}$ off the grid alignment). If instead, we were to assume a grid aligned at $20^{\circ}$ off of north (the dotted lines on the compass in Fig. 4), then the two bearings would have grid deviations of $35^{\circ}$ and $17.5^{\circ}$. Without confirming that a grid-layout was definitely present, one could still tentatively say on the basis of the lower deviations in the second case, that the offset grid was a better fit to the configuration of the three points than a NSEW one. As will be discussed below with regard to the real Baking Pot dataset, we can extend this approach to consider multiple nearest neighbours (closest, 2nd closest, 3rd closest etc.) and multiple grid-like alignments, until we find a best fit.

Fig. 5 applies this approach to three hypothetical datasets: (a) in which the location of 150 mounds is entirely random within the study area, (b) in which the mounds are generated very close $(<5 \mathrm{~m})$ to hypothetical gridlines offset $35^{\circ}$ west of north, and (c) a similar dataset where $80 \%$ of the mounds in b are retained, but where the further $20 \%$ are assumed to be 'noise' and hence are allocated entirely at random. In all three of these examples and the Baking Pot study that follows, we have chosen to include the bearings to both the first and the second closest neighbouring mounds, although the results are similar if we only stick to the nearest neighbour. In any case when we look at the first of these point patterns, we might expect the bearings of nearest neighbours to be distributed at random and to exhibit a uniform distribution of deviations from any chosen grid offset (with a mean deviation of $22.5^{\circ}$ ). Fig. $5 d$ demonstrates that this is so for a grid offset by $35^{\circ}$ from north. In contrast, Fig. 5e shows the distribution of deviations for the second pattern and the same grid alignment: there is a highly significant over-representation of small deviations and the mean deviation is correspondingly lower. We can take this analysis one step further and search across lots of different grid alignments for the one that minimises the mean deviation, and then test the significance of this minimum against the assumption of a uniform distribution (with a Kolmogorov-Smirnov test). Fig. 5f duly plots mean deviations for different grid alignments: the minima of these curves represent best fits to a particular grid, whilst the $p$ values at these minima suggest significance. In this case we can see that the underlying grid used to generate both patterns (b) and (c) is fairly accurately identified by this method, and in the case of (c), in the presence of fairly substantial noise. In contrast, pattern (a) is correctly shown to be random. 


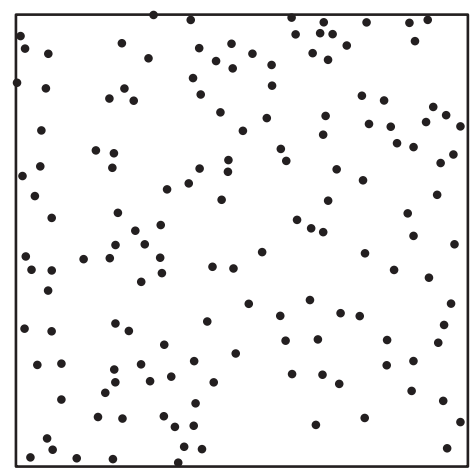

a

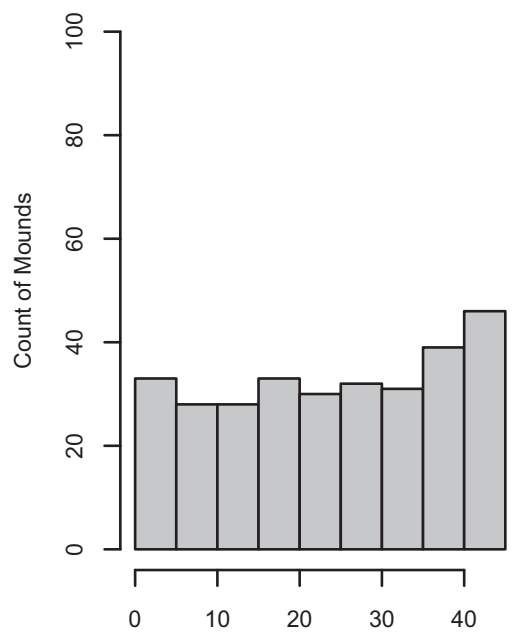

d Deviation of Neighbour Bearings from Grid

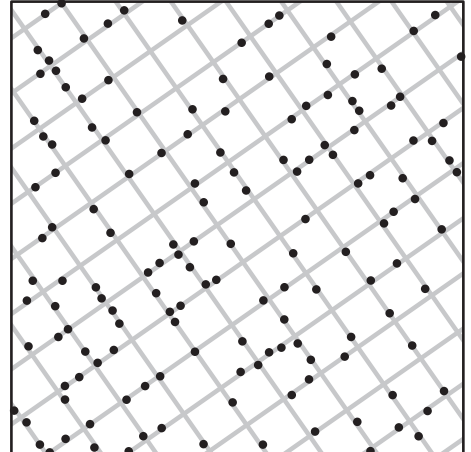

b

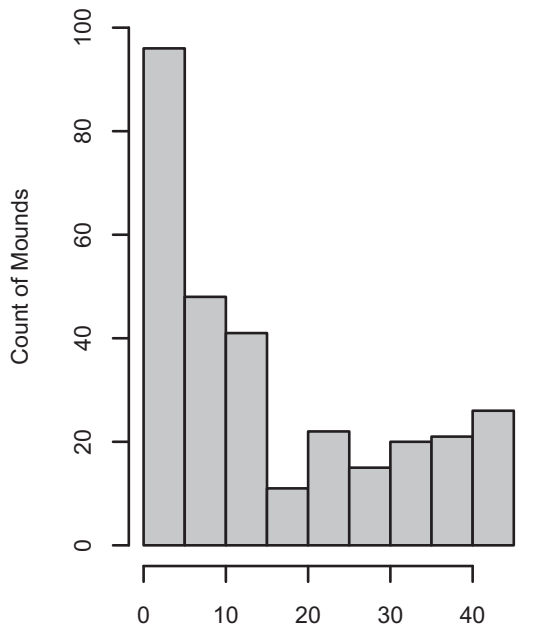

e Deviation of Neighbour Bearings from Grid

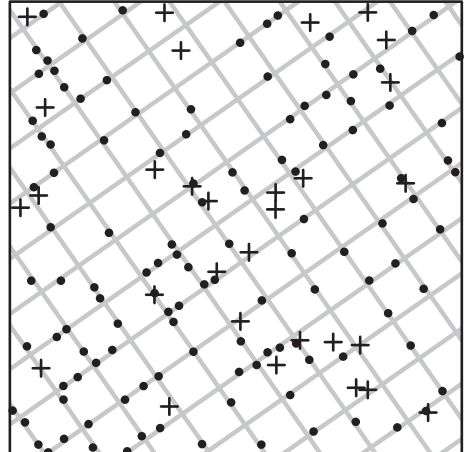

C

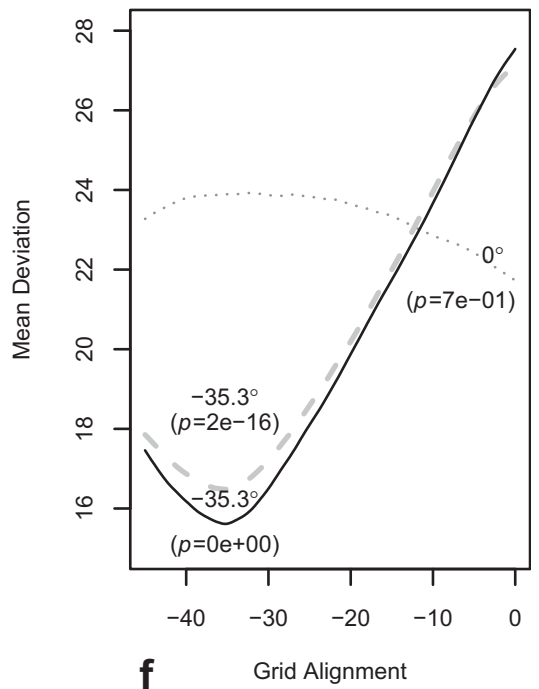

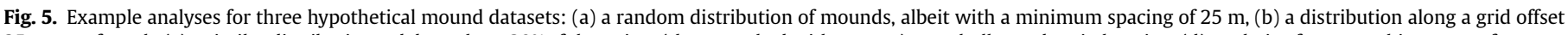

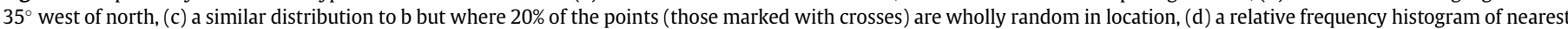

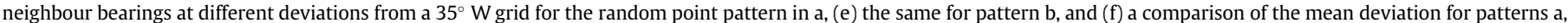
$\mathrm{b}$ and $\mathrm{c}$ relative to different grid alignments.

\section{Results and discussion}

If we turn our attention to the Baking Pot data, we can use the same method to search for the grid-offset that minimises the mean deviation of nearest neighbour bearings. Fig. 6 summarises these results for the six overlapping sub-regions we introduced above (Fig. 2a). What is interesting is that we have alignments that are more offset from north (in sub-regions 1-2 and 6), as we move out from the monumental epicentre of the site (sub-regions 3-5). It is difficult to be certain of the reasons for this, but it is tempting to suggest that the core of the site is earlier in date, and that whatever conscious rationale, or inadvertent process, led to the structuring of mounds in this way, changed over time as the polity expanded outwards. We will return to some of the interpretative possibilities below.

The observed spacing, grouping and alignment of mounds all prompt a range of further discussion, but perhaps the two most interesting aspects, in our view, are (a) what they might say about the nature of houseplots in the central Maya lowlands, and then more broadly, (b) what they might imply for the nature of Maya urbanism. A growing focus over the last few decades on settlement landscapes beyond monumental core of Maya sites has brought important changes in our overall understanding of Maya society. Settlement surveys conducted at larger Maya sites such as Tikal in

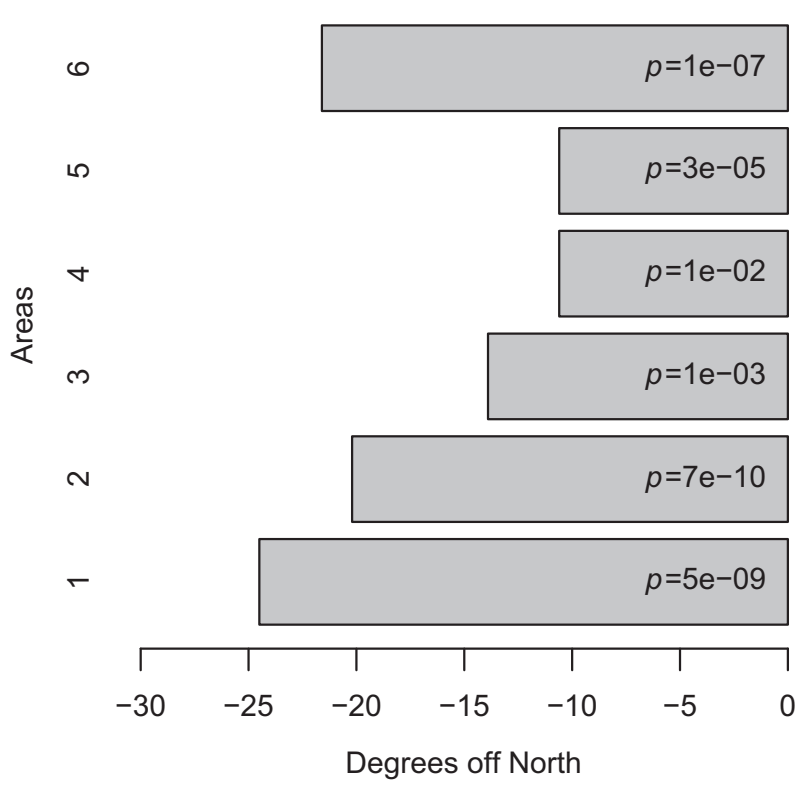

Fig. 6. The grid alignment that minimises mean deviation of nearest neighbour bearings for each sub-region (shown along with its $p$-value). 
Guatemala or Copan in Honduras have facilitated more sensible estimates of overall population, have recast our sense of what constitutes a Maya 'city', and have overturned a then established view that non-intensive slash-and-burn agriculture was the main means of Maya subsistence. Instead, more labour-intensive models of Maya agriculture have been proposed (Harrison and Turner, 1978; Sanders, 1979; Adams, 1980; Siemens, 1982; Lohse, 2004). Further intensive survey and remote sensing has also uncovered intensive agricultural terracing within and beyond the urban centre (e.g. Killion et al., 1989; Pyburn, 1998; Dunning, 1996; Chase et al., 2011), whereas close attention to the soils and remains around individual Maya houses has identified likely garden areas, fruit trees, beehives and turkey stocks (Kintz, 1990: 12-14; Ball and Kelsay, 1992; Fedick, 1995). Others have proposed that medicinal herbs, garden vegetables, and even maize were planted in the area close to the house (Anderson, 1998: 291; Becker, 2001: 440; Trigger, 2003: 302; Lohse, 2004: 129). Regardless of the exact mix of these activities, proximity to the house would have benefited from better moisture control, controlled inter-cropping, fertilization, protection from animals and general care, ensuring higher returns. Beyond this zone, there were definitely further out-fields. This model of intensive cultivation within urban landscapes and further agricultural activity beyond them is not unique to Maya area and should be seen as an increasingly well-documented feature of urbanism in the tropics (Chase, 1998; Graham, 1999; Fletcher, 2009, 2011).

In any case, the configuration of settlement at Baking Pot evokes this assumed diversity of practice nicely. The statisticallysignificant regular spacings exhibited by ordinary Maya housemounds constitute good evidence that families tended to keep their dwellings apart from one another. More precisely, the minimum spacings of at least $40-50 \mathrm{~m}$ between mounds might imply that each Late/Terminal Classic household typically made sole use of an area covering at least $500-600 \mathrm{~m}^{2}$ in their immediate vicinity, either as established by informal precedent or more formal tenure arrangements. Beyond this, there are clusters of mounds that we might realistically call suburban neighbourhoods, without attaching any specific western cultural baggage to this label, and in step with several other commentators who assert the same (Arnauld et al., 2004; Marcus, 2004; Smith, 2011). Between these there are open spaces: some no doubt reflect places where mounds once existed, where river movement and/or modern disturbance has destroyed them, but in many instances there are floodplains likely to have also existed in the Late Classic that might be used for agriculture and/or as public space. Beyond this is a combination of evidence both for more isolated field systems and dedicated agricultural installations (such as the canals surrounding the Bedran settlement group in the south-western periphery of Baking Pot, see Fig. 1 and below). The directional analysis conducted above also provides statistically-significant evidence for a grid-like structure to landholding and path systems at Baking Pot, at least in certain areas. We might therefore cautiously propose a series of rectilinear houseplots outlined by routes or paths running throughout the housemound landscape and following locally orthogonal alignments (although this still leaves entirely open the orientation of entrance to the houses themselves).

Such a model of micro-territoriality (involving small landholdings around each mound) and a rectilinear layout is certainly not one that has been stressed in existing studies of the central lowland Maya, and there is a risk that it will be seen as an inappropriate application of western urban models onto the Maya case. However, taking the issue of smalls-call tenure first, we can substantiate clear household plots further north at Maya sites in the Yucatan, often delimited by conspicuous features, such as fences, low walls and hedges (Alexander, 1999; Bullard, 1954; Fletcher and Kintz, 1983; Friedel, 1986; Friedel and Sabloff, 1984; also possibly
Killion et al., 1989). These features (walls, fences) are typically absent in the central lowlands (Becker, 2001: 430-435), but reconnaissance in the Roaring Creek valley $15-20 \mathrm{~km}$ to the east as the crow flies, revealed not only similar evidence for linear strings of regularly-spaced housemounds (unpublished, but see Helmke et al., 2004), but near a plazuela group in the Savannah Bank area, evenly-spaced small stone cairns along the eastern margin of the valley. These cairns undoubtedly served as boundary markers and are the kinds of features that typically go unrecorded for settlement surveys in jungle-covered areas, but which might conceivably be uncovered by more extensive stripping excavations at Baking Pot. It is also possible that, as in some other cases, these boundaries would have been marked only by perishable features, such as thorny bushes and trees (e.g. similar to European hedges or the willow and cypress lanes of the Aztec chinampa fields or garden boundary markers made of poles as in modern Yucatec towns and villages), which would allow stone and other building material to be kept for construction purposes (Becker, 2001; Fletcher and Kintz, 1983). This observation is especially true at Baking Pot, sited in the middle of the alluvial floodplain and several kilometres away from the nearest limestone quarry in the adjoining karstic foothills to the south. In many cases in the Yucatan area, there are also narrow pathways or corridors between the houseplots, allowing for pedestrians to pass through these plots without intruding upon them and in some instances causeways were used to delineate the houseplots (Becker, 2001, 432; see also Dahlin, 2000; Fletcher, 1983).

Turning to the second, yet more contentious question of a gridlike layout within local neighbourhoods of the site, we would stress that this is the first known instance, and we are not suggesting that such layouts are a ubiquitous feature of all urban landscapes across the central Maya lowlands, as considerable diversity can already be demonstrated both in time and space (Ford, 1990; Ashmore, 1998; Yaeger and Robin, 2004). Instead, we would simply argue that they are present in the vicinity of Late Classic Baking Pot and are an as yet under-appreciated way in which Maya settlement landscapes might occasionally be ordered in this region. Orthogonal layouts of cities are certainly a documented pre-conquest feature in central Mexico (e.g. Millon, 1973; Gasparini, 1993; Sanders and Webster, 1988) and South America (Gasparini, 1993; Gasparini and Margolies, 1980; Makowski, 2008; Smith, 2007), and alignments of urban spaces to conform to the cardinal directions are arguably a common cross-cultural feature of many early cities (Smith, 2007: 29). Indeed, Maya archaeologists have also been content to explore possibly alignments among monuments at the core of Maya sites (e.g. Aveni, 2003; Šprajc, 2008; but see Smith, 2003), without usually discussing what wider impact these might have on the surrounding, less ostentatious spaces.

In fact, the links between settlement alignments and monumental architecture at Baking Pot is worth pursuing further and the latter appears to have alignments that vary between 7 and $12^{\circ}$ west of north and may well shift increasingly west over time from the Late Preclassic to the Late Classic (e.g. Aimers, 1993: Table 5; Conlon and Powis, 2004; and personal observation). It is also clear that some of the causeways at Baking Pot follow directions that are then paraleled or extended by further alignments of housemounds at locations where a causeway surface is by no means obvious today, and where masonry foundations may never have existed. In other words, we should expect an interaction between the increasing monumentalism of certain directions in the core of a site and the arrangement of more mundane, non-elite spaces beyond this zone. Our model of housemounds shifting to more westerly alignments as our survey extends outwards from the monumental epicentre of Baking Pot may well reflect a spreading of settlement over the Classic period and thus potentially matches suggested 
westerly shifts in monumental alignments at the site, even if the exact bearings are not the same.

What causes these alignments (for comparative discussion, see also Grant, 2001)? For our purposes here, we prefer to set aside any specific speculation as to possible astronomical observations behind variation in orientation, but agree that such factors may have been important. There is also of course, some underlying inducement for houses to align themselves roughly parallel or perpendicular to the course of the Belize River, as this might improve drainage even in mostly flat areas such as Baking Pot. There are certainly also some instances where regular layouts of dwellings might emerge bottom-up from the face-to-face interactions of local inhabitants, and thereafter preserved by local custom. However, the traditional and most common interpretation of grid-like urban and rural layouts is that they are imposed as oneoff designs by top-down political authority (e.g. street grids and centuriated fields in Roman colonies, or possibly the Inca's imperial construction programs). Overall, despite the potential role for lower-level social conformism, we suspect that some level of official planning (e.g. by royal decree), played a role and a brief look at the Bedran plazuela group (bottom left in Fig. 1) in the southwestern periphery of the site may shed more light on this possibility. For example, both the formal artefact deposits and general architectural style of the eastern shrine (Structure 2) at Bedran mirror Baking Pot's southern monumental Group B (and at further remove therefore, also the monumental epicentres of Cahal Pech, Buenavista, Río Azul and Tikal; Conlon et al., 1994: 254; Helmke and Awe, 2008b: 88-90). Such replication of architecture and assemblage was probably meant to express the elevated social status of inhabitants of Bedran Group in comparison to residents of other lower-order housemounds in the vicinity (Willey et al., 1965: 572; Colas et al., 2002: 33-34; Conlon and Powis, 2004: 75). More interesting in terms of the present discussion is the fact that an elaborate ditched field system built across some 64 ha surrounding the Bedran settlement cluster conforms to the wider alignments of housemounds (Fig. 1; Kirke, 1980; Conlon and Powis, 2004). This ditched field system was a capital investment that was probably meant to encourage the production of agricultural surpluses by local inhabitants with close links to the Baking Pot elite. The alignments of these ditches is noticeably similar to that observed in the Baking Pot housemounds, and while underlying landscape factors such as common drainage directions, should not be ruled out entirely, we suspect that organisational similarities are consciously imposed ones.

In any case, this paper has sought to explore the Baking Pot settlement data via comparatively novel spatial analysis methods, and as suggested above, there are plenty of ways in which such approaches could be developed further. Some small but important features of the observed spatial patterning at Baking Pot also suggest ways that Maya archaeologists might revisit existing debates about land use, tenure practices and urban form from new and productive angles.

\section{Acknowledgements}

We would like to thank Elizabeth Graham for advice at various stages as well as to James Conlon for productive discussions pertaining to the settlement survey of Baking Pot. Julie Hoggarth is acknowledged for her close collaboration in this project, her doctoral research focusing on sampling the settlement by means of surface collections and excavations. We are also indebted to the Belize Institute of Archaeology for issuing the permits necessary to conduct the research reported on here, as well as for the continued support they have extended to the BVAR project. Thanks also to the JAS anonymous reviewers.

\section{References}

Adams, R.E.W., 1980. Swamps, canals, and the location of ancient Maya cities. Antiquity 54 (212), 206-214.

Aimers, J.J., 1993. "Messages from the Gods": a Hermeneutic Analysis of the Maya EGroup Complex. MA thesis, Trent University, Peterborough.

Alexander, R., 1999. Mesoamerican house lots and archaeological site structure: problems of inference in Yaxcaba, Yucatan, Mexico. In: Allison, P.M. (Ed.), The Archaeology of Household Activities. Routledge, London, pp. 1750-1847.

Anderson, E.N., 1998. Gardens of Chunhuhub. In: Memorias del Tercer Congreso Internacional de Mayistas. U.N.A.M, Mexico D. F., pp. 291-310.

Arnauld, M., Breuil-Martínez, V., et Alvarado, É., 2004. La Joyanca (La Libertad, Guatemala): antigua ciudad maya del noroeste del Petén. Centro Francés de Estudios Mexicanos y Centroamericanos (CEMCA),/Antigua: Asociación Tikal, Guatemala City/Centro de Investigaciones Regionales de Mesoamérica (CIRMA), Mexico City.

Ashmore, W., 1981. Some issues of method and theory in lowland Maya settlement archaeology. In: Ashmore, Wendy (Ed.), Lowland Maya Settlement Patterns. University of New Mexico Press, Albuquerque, pp. 37-70.

Ashmore, W., 1998. Monumentos politicos: Sitio, asentamiento y paisaje alrededor de Xunantunich, Belice. In: Ruiz, A.C., Marquínez, Y.F., Ponce de León, M.J., Lacadena García-Gallo, A., Sanz Castro, L.T. (Eds.), Anatomía de una civilización: Aproximaciones inter-disciplinarias a la cultura maya. Sociedad Española de Estudios Mayas, Madrid, pp. 161-183.

Aveni, A.F., Dowd, A.S., Vining, B., 2003. Maya calendar reform? Evidence from orientations of specialized architectural assemblages. Latin American Antiquity 14 (2), 159-178.

Aveni, A.F., 2001. Skywatchers. University of Texas Press, Austin.

Aveni, A.F., 2003. Archaeoastronomy in the ancient Americas. Journal of Archaeological Research 11, 149-191.

Ball, J.W., Kelsay, R.G., 1992. Prehistoric intrasettlement land use and residual soil phosphate levels in the upper Belize valley, Central America. In: Killion, T.W. (Ed.), Gardens of Prehistory: The Archaeology of Settlement Agriculture in Greater Mesoamerica. University of Alabama Press, Tuscaloosa, pp. 234-262.

Bartlett, M.S., 1964. The spectral analysis of two-dimensional point processes. Biometrika 51 (3-4), 299-311.

Becker, M.J., 1971. The Identification of a Second Plaza Plan at Tikal, Guatemala, and Its Implications for Ancient Maya Social Complexity. PhD dissertation, Department of Anthropology, University of Pennsylvania, Philadelphia.

Becker, M.J., 1999. Excavations in Residential Areas of Tikal: Groups with Shrines. In: University Museum Monograph 104, Tikal Report 21. University of Pennsylvania, Philadelphia.

Becker, M.J., 2001. Houselots at Tikal, Guatemala: it's what's out back that counts. In: Ruiz, A.C., Ponce de León, M.J.I., del Carmen Martínez Martínez, M. (Eds.), Reconstruyendo la Ciudad Maya: el Urbanismo en las Sociedades Antiguas. Publicaciones de la SEEM, no. 6. Sociedad Española de Estudios Mayas, Madrid, pp. $427-460$.

Benito-Calvo, A., de la Torre, I., 2011. Analysis of orientation patterns in Olduvai Bed I assemblages using GIS techniques: implications for site formation processes. Journal of Human Evolution 61, 50-60.

Bevan, A., Conolly, J., 2006. Multiscalar approaches to settlement pattern analysis. In: Lock, G., Molyneaux, B. (Eds.), Confronting Scale in Archaeology: Issues of Theory and Practice. Springer, New York, pp. 217-234.

Bevan, A., Conolly, J., 2009. Modelling spatial heterogeneity and nonstationarity in artifact-rich landscapes. Journal of Archaeological Science 36 (4), 956-964.

Bevan, A., Crema, E., Li, X., Palmisano, A. Intensities, interactions and uncertainties: some new approaches to archaeological distributions. In: Bevan, A., Lake, M. (Eds.), Computational Approaches to Archaeological Spaces, Walnut Creek. Left Coast Press. Distributions (Book Chapter), in press.

Bove, F.J., 1981. Trend surface analysis and the Lowland Classic Maya collapse. American Antiquity 46, 93-112.

Brown, C.T., Witschey, R.T., 2003. The fractal geometry of ancient Maya settlement. Journal of Archaeological Science 30 (12), 1619-1632.

Bullard, W.R., Bullard, M.R., 1965. Late Classic Finds at Baking Pot, British Honduras. Royal Ontario Museum, Toronto.

Bullard, W.R., 1954. Boundary Walls and House Lots at Mayapan (Current Report No. 13). Carnegie Institution of Washington, Department of Archaeology, Washington D.C.

Chase, A.F., Chase, D.Z., 1994. Maya veneration of the dead at Caracol, Belize. In: Greene-Robertson, M., Fields, V.M. (Eds.), Seventh Palenque Round Table 1989. Pre-Columbian Art Research Institute, San Francisco, pp. 55-62.

Chase, A.F., Chase, D.Z., 2001. Ancient Maya causeways and site organization at Caracol, Belize. Ancient Mesoamerica 12 (2), 273-281.

Chase, A., Garber, J., 2004. The archaeology of the Belize valley in historical perspective. In: Garber, J. (Ed.), The Ancient Maya of the Belize Valley. Half a Century of Archaeological Research. University Press of Florida, Gainesville, pp. 1-14.

Chase, A.F., Chase, D.Z., Weishampel, J.F., Drake, J.B., Shrestha, R.L., Slatton, K.C., Awe, J.J., Carter, W.E., 2011. Airborne LiDAR, archaeology, and the ancient Maya landscape at Caracol, Belize. Journal of Archaeological Science 38, 387-398.

Chase, A.F., 1998. Scale and intensity in Classic Period Maya agriculture: terracing and settlement at the "garden city" of Caracol, Belize. Culture and Agriculture 20, 60-77.

Chase, A.F., 2004. Polities, politics, and social dynamics: contextualizing the archaeology of the Belize Valley and Caracol. In: Garber, J.F. (Ed.), The Ancient 
Maya of the Belize Valley. Half a Century of Archaeological Research. University Press of Florida, Gainesville, pp. 320-334.

Colas, P.R., Helmke, C.G.B., Awe, J.J., Powis, T.G., 2002. Epigraphic and ceramic analyses of two Early Classic Maya vessels from Baking Pot, Belize. Mexicon 24 (2), 33-39.

Conlon, J.M., Awe, J.J., 1995. Estimates of population and agrarian potential for the ditched field irrigation system at Baking Pot, Belize. In: Conlon, James M., Awe, Jaime J. (Eds.), Belize Valley Archaeological Reconnaissance Project: Progress Report of the 1994 Field Season, vol. 2. Institute of Archaeology, University College London, London, pp. 63-79.

Conlon, J.M., Ehret, J.J., 2000. Ancient Maya settlement at Baking Pot, Belize: results of the continually expanding survey program in the search for the end of the final frontier. In: Griffith, C.S., Ishihara, R., Awe, J.J. (Eds.), The Western Belize Regional Cave Project: a Report of the 1999 Field Season. Department of Anthropology Occasional Paper No. 3. University of New Hampshire, Durham, NH, pp. 43-54.

Conlon, J.M., Powis, T.G., 2004. Major center identifiers at a plazuela group near the ancient Maya site of Baking Pot. In: Garber, J.F. (Ed.), The Ancient Maya of the Belize Valley. Half a Century of Archaeological Research. University Press of Florida, Gainesville, pp. 70-85.

Conlon, J.M., Powis, T., Hohmann, R., 1994. Ruler or ruled? Status, land tenure, and nucleated settlement in the western periphery of Baking Pot, Belize. In: Conlon, J.M., Awe, J.J. (Eds.), Belize Valley Archaeological Reconnaissance Project: Progress Report of the 1993 Field Season. Institute of Archaeology, University College London, London, pp. 224-262.

Conlon, J.M., 1997. An analysis of ancient Maya consumption requirements and agricultural production potential at Baking Pot, Belize. In: Awe, J.J., Conlon, J.M. (Eds.), Belize Valley Archaeological Reconnaissance Project: Progress Report of the 1996 Field Season. Department of Anthropology, Trent University, Peterborough, pp. 7-20.

Crema, E.R., Bevan, A., Lake, M., 2010. A probabilistic framework for assessing spatio-temporal point patterns in the archaeological record. Journal of Archaeological Science 37, 1118-1130.

Dahlin, B.H., 2000. The Barricade and Abandonment of Chunchucmil: implications for Northern Maya Warfare. Latin American Antiquity 11 (3), 283-298.

Dale, M.R.T., Mah, M., 1998. The use of wavelets for spatial pattern analysis in ecology. Journal of Vegetation Science 9, 805-814.

de Smith, M., Longley, P., Goodchild, M., 2009. Geospatial Analysis: a Comprehensive Guide to Principles, Techniques and Software Tools, third ed. Troubadour, Leicester.

Douglass, J.G., 2002. Hinterland Households: Rural Agrarian Household Diversity in Northwest Honduras. University Press of Colorado, Boulder.

Driver, W.D., Garber, J.F., 2004. The emergence of minor centers in the zones between seats of power. In: Garber, J.F. (Ed.), The Ancient Maya of the Belize Valley. Half a Century of Archaeological Research. University Press of Florida, Gainesville, pp. 287-304.

Dunning, N.P., 1996. An examination of regional variability in the prehispanic Maya agricultural landscape. In: Fedick, Scott L. (Ed.), The Managed Mosaic: Ancient Maya Agriculture and Resource Management. University of Utah Press, Salt Lake City, pp. 53-68.

Dunning, N., 2004. Down on the farm: Classic Maya "Homesteads" as "Farmsteads". In: Lohse, J., Valdez Jr, F. (Eds.), Ancient Maya Commoners. University of Texas Press, Austin, pp. 97-116.

Falsetti, A.B., Sokal, R.R., 1993. Genetic structure of human populations in the British Isles. Annals of Human Biology 20, 215-229.

Fedick, S.L., 1995. Land evaluation and ancient Maya land use in the upper Belize river area, Belize, Central America. Latin American Antiquity 6 (1), 16-34.

Fletcher, L., Kintz, E., 1983. Solares, kitchen gardens, and social status at Coba. In: Folan, W., Kintz, E., Fletcher, L. (Eds.), Coba: a Classic Maya Metropolis. Academic Press, New York. Pages.

Fletcher, L., 1983. Coba and Mayapan: a comparison of solares, household variation, sociopolitical organization, and land tenure. In: Folan, W., Kintz, E., Fletcher, L. (Eds.), Coba: a Classic Maya Metropolis. Academic Press, New York, pp. 121-131.

Fletcher, R., 2009. Low-density, Agrarian-based Urbanism: a Comparative View, Insights (University of Durham), vol. 2. Article 4.

Fletcher, R., 2011. Low-density, agrarian-based urbanism: scale, power and ecology. In: Smith, Michael E. (Ed.), The Comparative Archaeology of Complex Societies. Cambridge University Press, New York, pp. 285-320.

Ford, A., 1990. Maya settlement in the Belize river area: variations in residence patterns of the central Maya lowlands. In: Patrick Culbert, T., Rice, Don S. (Eds.), Precolumbian Population History in the Maya Lowlands. University of New Mexico Press, Albuquerque, pp. 167-181.

Friedel, D., Sabloff, J., 1984. Cozumel: Late Maya Settlement Patterns. Academic Press, New York.

Friedel, D.A., 1986. Yaxuna Archaeological Survey: a Report of the 1986 Field Season. Report Submitted to the Comittee for Research and Exploration. National Geographic Society, Washington, D.C.

Fry, N., 1979. Random point distributions and strain measurement in rocks'. Tectonophysics $60,89-105$.

Garber, J.F., Driver, W.D., Sullivan, L.A., 1993. Site alignments and sociopolitical systems of the valley. In: Garber, J.F., Driver, W.D., Sullivan, L.A. (Eds.), The Blackman Eddy Archaeological Project: Results of the 1992 Field Season. Southwest Texas State University, San Marcos, pp. 15-22.

Gasparini, G., Margolies, L., 1980. Inka Architecture. Indiana University Press, Bloomington.
Gasparini, G., 1993. The pre-hispanic grid system: the urban shape of conquest and territorial organisation. In: Bennett, R. (Ed.), Settlements in the Americas Crosscultural Perspectives. Associated University Presses, Inc., London. Pages.

Gelfand, A.E., Diggle, P.J., Fuentes, M., Guttorp, P., 2010. Handbook of Spatial Statistics. CRC/Taylor and Francis, London.

Graham, E.A., 1999. Stone cities, Green cities. In: Bacus, E.A., Lucero, L.J. (Eds.) Complex Polities in the Ancient Tropical World. Archaeological Papers 9. American Anthropological Association, Arlington, pp. 185-194.

Grant, J., 2001. The dark side of the grid: power and urban design. Planning Perspectives 16 (3), 219-241.

Haase, P., 2001. Can isotropy vs. anisotropy in the spatial association of plant species reveal physical vs. biotic facilitation? Journal of Vegetation Science 12 (1), 127-136.

Harrison, P.D., Turner, B.L., 1978. Prehispanic Maya Agriculture. University of New Mexico Press, Albuquerque.

Haynes, K.E., Enders, W.T., 1975. Distance, direction, and entropy in the evolution of a settlement pattern. Economic Geography 51 (4), 357-365.

Healy, P.F., Helmke, C.G.B., Awe, J.J., Sunahara, K.S., 2007. Survey, settlement, and population history at the ancient Maya site of Pacbitun, Belize. Journal of Field Archaeology 32 (1), 17-39.

Helmke, C., Awe, J., 2008a. Organización territorial de los antiguos mayas de Belice Central: confluencia de datos arqueológicos y epigráficos. Mayab 20, 65-91.

Helmke, C., Awe, J., 2008b. New Site Description and Structure Designations of Baking Pot, Belize. In: The Belize Valley Archaeological Reconnaissance Project: a Report of the 2007 Field Season, vol. 13, pp. 81-102.

Helmke, C., Awe, J., 2013. Ancient Maya territorial organisation of central Belize: confluence of archaeological and epigraphic data. Contributions in New World Archaeology 4, 57-88.

Helmke, C., Bevan, A., Awe, J., 2004. Roaring creek: life along an ancient Maya valley. Current World Archaeology 4, 10-16.

Hodder, I., Orton, C., 1976. Spatial Analysis in Archaeology. Cambridge University Press, Cambridge.

Hoggarth, J.A., Jobbová, E., Helmke, C., Bevan, A., 2008. Settlement Survey at Baking Pot, Belize: Results of the 2007 Season. In: The Belize Valley Archaeological Reconnaissance Project: A Report of the 2007 Field Season, vol. 13. 157-187.

Houston, S.D., 1993. Hieroglyphs and History at Dos Pilas: Dynastic Politics of the Classic Maya. University of Texas, Austin.

Hutson, S.R., Magnoni, A., Stanton, T.W., 2004. House rules? The practice of social organization in Classic-period Chunchucmil, Yucatan, Mexico. Ancient Mesoamerica 15, 75-92.

Hutson, S.R., Stanton, T.W., Magnoni, A., Terry, R., Craner, J., 2007. Beyond the buildings: formation processes of ancient Maya houselots and methods for the study of non-architectural space. Journal of Anthropological Archaeology 26 $442-473$.

Iannone, G., Connell, S.V. (Eds.), 2003. Perspectives on Ancient Maya Rural Complexity. Cotsen Institute of Archaeology, Los Angeles.

Illian, J., Penttinen, A., Stoyan, H., Stoyan, D., 2008. Statistical Analysis and Modelling of Spatial Point Patterns. Wiley-Interscience, New York.

Killion, T.W., Sabloff, J.A., Tourtellot, G., Dunning, N., 1989. Intensive surface collection of residential clusters at Terminal Classic Sayil, Yucatán, Mexico. Journa of Field Archaeology 16 (2), 273-294.

Kintz, E.R., 1990. Life Under the Tropical Canopy: Tradition and Change Among the Yucatec Maya. Holt, Rinehart and Winston, Fort Worth.

Kirke, C.M., 1980. Prehistoric agriculture in the Belize river valley. World Archaeology 2 (3), 281-286.

Kvamme, K.L., 1990. Spatial autocorrelation and the Classic Maya collapse revisited. Journal of Archaeological Science 17, 197-207.

Lohse, J.C., 2004. Intra-site settlement signatures and implications for Late Classic Maya Commoner organization at Dos Hombres, Belize. In: Lohse, J., Valdez Jr, F. (Eds.), Ancient Maya Commoners. University of Texas Press, Austin, pp. 117-145.

Makowski, K., 2008. Andean urbanism. In: Silverman, H., Isbell, W. (Eds.), Handbook of South American Archaeology. Springer Science + Business Media, LLC, New York, pp. 633-657.

Manaham, T.K., Canuto, M.A., 2009. Bracketing the Copan Dynasty: Late Preclassic and Early Postclassic settlements at Copan, Honduras. Latin American Antiquity 20 (4), 553-580.

Marcus, J., 2004. Maya commoners: the stereotype and the reality. In: Lohse, Jon C., Valdez Jr, Fred (Eds.), Ancient Maya Commoners. University of Texas Press, Austin, pp. 255-283.

Marken, D., 2011 City and State: Urbanism, Rural Settlement, and Polity in the Classic Maya Lowlands. Ph.D. dissertation, Southern Methodist University Dallas.

Markofsky, S., Bevan, A., 2011. Directional analysis of surface artefact distributions. A case study from the Murghab Delta, Turkmenistan. Journal of Archaeological Science 39 (2), 428-439.

Mathews, P., 1991. Classic Maya emblem glyphs. In: Patrick Culbert, T. (Ed.), Classic Maya Political History: Hieroglyphic and Archaeological Evidence. School of American Research Advanced Seminar Series. University of Cambridge Press, Cambridge, pp. 19-29.

Millon, R., 1973. Urbanization at Teotihuacán, Mexico. In: The Teotihuacán Map, Part One: Text, vol. 1. University of Texas Press, Austin.

Mugglestone, M.A., Renshaw, E., 1996. A practial guide to the spectral analysis of spatial point processes. Computational Statistics and Data Analysis 21, 43-65.

Neiman, F.D., 1997. Conspicuous consumption as wasteful advertising: a Darwinian perspective on spatial patterns in Classic Maya terminal monument dates. In: 
Barton, C., Clark, G. (Eds.), Re-discovering Darwin: Evolutionary Theory and Archaeological Explanation. Archaeological Papers of the American Anthropological Association 7, pp. 267-290.

Nicolis, O., Mateu, J., D'Ercole, R., 2010. Testing for anisotropy in spatial point processes. In: González-Manteiga, W., Crujeiras, R.M., Martinez-Calvo, A., FebreroBande, M., Fernandez-Casal, R., Ginzo-Villamayor, M.J., Pateio-Lopez, B. (Eds.), Proceedings of the Fifth International Workshop on Spatio-temporal Modelling (METMA5). Publisher Unidixital, Santiago de Compostela, pp. 1-4.

Normark, J., 2006. The Roads In-between: Causeways and Polyagentive Networks at Ichmul and Yo'okop, Cochuah Region, Mexico. Doctoral dissertation, Göteborg University, Göteborg.

Oden, N.L., Sokal, R.R., 1986. Directional autocorrelation: an extension of spatial correlograms to two dimensions. Systematic Zoology 35, 608-617.

Orton, C., 2004. Point pattern analysis revisited. Archeologia e Calcolatori 15, $299-315$.

Premo, L.S., 2004. Local spatial autocorrelation statistics quantify multi-scale patterns in distributional data: an example from the Maya Lowlands. Journal of Archaeological Science 31, 855-866.

Pyburn, K.A., 1998. The Albion Island settlement pattern project: domination and resistance in early Classic Northern Belize. Journal of Field Archaeology 25, 37-62.

Rayner, J.N., Golledge, R.G., 1972. Spectral analysis of settlement patterns in diverse physical and economic environments. Environment and Planning 4, 347-371.

Ricketson, O.G., 1929. Excavations at Baking Pot, British Honduras. In: Contributions to American Anthropology and History 1(403). Carnegie Institution of Washington, Washington.

Robert, C.P., Casella, G., 2004. Monte Carlo Statistical Methods, second ed. Springer, New York.

Rosenberg, M.S., 2000. The bearing correlogram: a new method of analysing directional spatial autocorrelation. Geographical Analysis 32, 267-278.

Sanders, W.T., Webster, D., 1988. The Mesoamerican urban tradition. American Anthropologist 90, 521-546.

Sanders, W.T., 1979. The Fon of Bafut and the Classic Maya. In: 42nd International Congress of Americanists (Paris, 1976). 389-399.
Siemens, A.H., 1982. Prehispanic agricultural use of the wetlands of Northern Belize. In: Flannery, K.V. (Ed.), Maya Subsistence: Studies in Memory of Dennis E. Puleston. Academic Press, New York, pp. 205-226.

Smith, M.E., 2003. Can we read cosmology in ancient Maya city plans? Comment on Ashmore and Sabloff. Latin American Antiquity 14 (2), 221-228.

Smith, M.E., 2007. Form and meaning in the earliest cities: a new approach to ancient urban planning. Journal of Planning History 6 (1), 3-47.

Smith, M.E., 2011. Classic Maya settlement clusters as urban neighbourhoods: a comparative perspective on low-density urbanism. Journal de la Société des Américanistes 97 (1), 51-73.

Šprajc, I., 2008. More on Mesoamerican cosmology and city plans. In: Aveni, A. (Ed.), Foundations of New World Cultural Astronomy. University Press of Colorado, Boulder, pp. 772-782.

Stuart, D., 2006. The Inscribed Markers of the Coba-yaxuna Causeway and the Glyph for Sakbih. Mesoweb: www.mesoweb.com/stuart/notes/sacbe.pdf.

Trigger, B.G., 2003. Understanding Early Civilizations: a Comparative Study. Cambridge University Press, Cambridge.

Whitley, D.S., Clark, W.A.V., 1985. Spatial autocorrelation tests and the Classic Maya collapse: methods and inferences. Journal of Archaeological Science 12, 377-395.

Willey, G.R., Bullard Jr., W.R., Glass, J.B., Gifford, J.C., 1965. Prehistoric Maya Settlements in the Belize Valley. In: Papers of the Peabody Museum of Archaeology and Ethnology. Harvard University, Cambridge.

Williams, J.T., 1993. Spatial autocorrelation and the Classic Maya collapse: one technique, one conclusion. Journal of Archaeological Science 20, 705-709.

Wilson, S.M., Melnick, D.J., 1990. Modelling randomness in locational archaeology. Journal of Archaeological Science 17 (4), 403-412.

Yaeger, J., Robin, C., 2004. Heterogeneous hinterlands: the social and political organization of commoner settlements near Xunantunich, Belize. In: Lohse, J., Valdez Jr, F. (Eds.), Ancient Maya Commoners. University of Texas Press, Austin, pp. 147-173.

Yaeger, J., 2000. Changing Patterns of Social Organization: the Late and Terminal Classic Communities at San Lorenzo, Cayo District, Belize. PhD dissertation, University of Pennsylvania, Philadelphia. 